\title{
An integer programming approach for process planning for mixed-model parts manufacturing on a CNC machining center
}

\author{
Kongchuenjai, J., ${ }^{a}{ }^{,}$, Prombanpong, S. $^{a}$ \\ a King Mongkut's University of Technology Thonburi (KMUTT), Department of Production Engineering, Bangkok, Thailand
}

\begin{abstract}
A B S T R A C T
The manufacturing system for mixed parts is prevalent in many industries due to the continuous demand of product variety. Thus, the mathematical model to design a process plan is developed by using the integer linear programming. The main aim is to minimize the total production time. The main time factors included in the model composed of the machining time, tool traveling time, tool changing time and tombstone face changing time. The significant design constraints are the precedence operations, fixture design, and available cutting tool constraints. Furthermore, a variation of part styles is also accounted for in this study as the different types of a part can be concurrently mounted and processed which makes this problem unique. Therefore, this problem is much more complex than the normal single model process planning. The model developed using integer programming will determine a sequence of required machining operations. It also decides the face of the machining part to be fastened on the tombstone face. In addition, a suitable cutting tool will be selected based on minimum total production time. The result of this paper, aids in solving process planning difficulty in the dedicated flexible manufacturing system in the era of Industry 4.0.
\end{abstract}

\section{ARTICLE INFO}

Keywords:

Flexible manufacturing system

Process planning (CAPP)

Mixed-model

Integer programming

*Corresponding author:

janjiraie@yahoo.com

(Kongchuenjai, J.)

Article history:

Received 11 April 2017

Revised 10 July 2017

Accepted 16 July 2017

\section{References}

[1] Li, X., Zhang, C., Gao, L., Li, W., Shao, X. (2010). An agent-based approach for integrated process planning and scheduling, Expert Systems with Applications, Vol. 37, No. 2, 1256-1264, doi: 10.1016/i.eswa.2009.06.014.

[2] Demir, Y., İşleyen, S.K. (2013). Evaluation of mathematical models for flexible job-shop scheduling problems, Applied Mathematical Modeling, Vol. 37, No. 3, 977-988, doi: 10.1016/j.apm.2012.03.020.

[3] Šeda, M. (2007). Mathematical models of flow shop and job shop scheduling problems, International Journal of Applied Mathematics and Computer Science, Vol. 4, No. 4, 241-246.

[4] Li, X., Gao, L., Shao, X., Zhang, C., Wang, C. (2010). Mathematical modeling and evolutionary algorithm-based approach for integrated process planning and scheduling, Computers \& Operations Research, Vol. 37, No. 4, 656667, doi: 10.1016/i.cor.2009.06.008.

[5] Jahromi, M.H.M.A., Tavakkoli-Moghaddam, R. (2012). A novel 0-1 linear integer programming model for dynamic machine-tool selection and operation allocation in a flexible manufacturing system, Journal of Manufacturing Systems, Vol. 31, No. 2, 224-231, doi: 10.1016/i.jmsy.2011.07.008.

[6] Nourali, S., Imanipour, N., Shahriari, M.R. (2012). A mathematical model for integrated process planning and scheduling in the flexible assembly job shop environment with sequence dependent setup times, International Journal of Mathematical Analysis, Vol. 6, No. 43, 2117-2132.

[7] Deja, M., Siemiatkowski, M.S. (2013). Feature-based generation of machining process plans for optimized parts manufacture, Journal of Intelligent Manufacturing, Vol. 24, No. 4, 831-846, doi: 10.1007/s10845-012-0633-x. 
[8] Zeballos, L.J., Quiroga, O.D., Henning, G.P. (2010). A constraint programming model for the scheduling of flexible manufacturing systems with machine and tool limitations, Engineering Applications of Artificial Intelligence, Vol. 23, No. 2, 229-248, doi: 10.1016/j.engappai.2009.07.002.

[9] Zeballos, L.J. (2010). A constraint programming approach to tool allocation and production scheduling in flexible manufacturing systems, Robotics and Computer-Integrated Manufacturing, Vol. 26, No. 6, 725-743, doi: 10.1016/ j.rcim. 2010.04.005.

[10] Karakayalı, I., Azizoğlu, M. (2006). Minimizing total flow time on a single flexible machine, International Journal of Flexible Manufacturing Systems, Vol. 18, No. 1, 55-73, doi: 10.1007/s10696-006-9000-6.

[11] Chandra, P., Li, S., Stan, M. (1993). Jobs and tool sequencing in an automated manufacturing environment, International Journal of Production Research, Vol. 31, No. 12, 2911-2925, doi: 10.1080/00207549308956907.

[12] Li, X., Gao, L., Li, W. (2012). Application of game theory based hybrid algorithm for multi-objective integrated process planning and scheduling, Expert Systems with Applications, Vol. 39, No. 1, 288-297, doi: 10.1016/i.eswa. 2011.07.019.

[13] Akturk, M.S., Avci, S. (1996). An integrated process planning approach for CNC machine tools, The International Journal of Advanced Manufacturing Technology, Vol. 12, No. 3, 221-229, doi: 10.1007/bf01351201.

[14] Das, K., Baki, M.F., Li, X. (2009). Optimization of operation and changeover time for production planning and scheduling in a flexible manufacturing system, Computers \& Industrial Engineering, Vol. 56, No. 1, 283-293, doi: 10.1016/j.cie.2008.06.001.

[15] Ahmad, I., Al-aney, K.I.M. (2009). Loading and sequencing jobs with the fastest machine among others, Advances in Production Engineering \& Management, Vol. 4, No. 3, 127-138.

[16] Özgüven, C., Özbakır, L., Yavuz, Y. (2010). Mathematical models for job-shop scheduling problems with routing and process plan flexibility, Applied Mathematical Modelling, Vol. 34, No. 6, 1539-1548, doi: 10.1016/j.apm.2009. 09.002.

[17] Prombanpong, S., Lewis, R.L., Bishop, A.B. (1992). A computer-aided fixture design system with process planning integration for prismatic parts manufactured on CNC machining centers, In: Computers in Engineering, Proceedings of the International Computers in Engineering Conference and Exhibition, San Francisco, USA, 369-380.

[18] Xu, X., Wang, L., Newman, S.T. (2011). Computer-aided process planning - A critical review of recent developments and future trends, International Journal of Computer Integrated Manufacturing, Vol. 24, No. 1, 1-31, doi: 10.1080/0951192X.2010.518632.

[19] Kongchuenjai, J., Prombanpong, S. (2015). An optimization of automated process planning for manufacturing prismatic parts on a machining center, Applied Mechanics and Materials, Vol. 789-790, 1270-1274, doi: 10.4028/www.scientific.net/AMM.789-790.1270. 


\section{APEM}

\title{
Pristop s celoštevilskim programiranjem za načrtovanje proizvodnje mešanih izdelkov na CNC obdelovalnem centru
}

\author{
Kongchuenjai, J. ${ }^{\mathrm{a},{ }^{*}}$, Prombanpong, $\mathrm{S}^{\mathrm{a}}$ \\ a King Mongkut's University of Technology Thonburi (KMUTT), Department of Production Engineering, Bangkok, Thailand
}

\section{POVZETEK}

Zaradi nenehnega povpraševanja po raznolikosti izdelkov v mnogih industrijskih panogah prevladujejo proizvodni sistemi za izdelavo mešanih izdelkov. Zato smo razvili matematični model za načrtovanje procesa z uporabo celoštevilskega linearnega programiranja. Glavni cilj je bil skrajšanje skupnega proizvodnega časa. Glavni vplivni dejavniki v modelu so bili obdelovalni čas, čas potovanja orodja, čas menjave orodja in čas menjave vpenjalne mize. Pomembni omejitveni kriteriji so bile prednostne operacije, zasnova vpenjalne naprave in razpoložljive omejitve orodja. Upoštevane so bile različne variacije izdelkov, ki se lahko istočasno vpnejo in obdelajo, zaradi česar je problem edinstven in kompleksnejši od načrtovanja procesa za proizvodnjo enega izdelka. Razvit model določi zaporedje zahtevanih postopkov obdelave. Rezultati objavljeni v prispevku pripomorejo k reševanju težav, povezanih z načrtovanjem procesa obdelave na prilagodljivih obdelovalnih sistemih v luči industrije 4.0.
\end{abstract}

(C) 2017 PEI, University of Maribor. All rights reserved.

\section{PODATKI O ČLANKU}

Ključne besede:

Prilagodljiv proizvodni sistem

Načrtovanje procesov (CAPP)

Mešani model

Celoštevilsko programiranje

*Kontaktna oseba: janjiraie@yahoo.com

(Kongchuenjai, J.)

Zgodovina članka:

Prejet 11. aprila 2017

Popravljen 10. julija 2017

Sprejet 16. julija 2017 